\title{
Localization of the Urban Workforce Reproduction of the Modern City
}

\author{
Anna I. Pakhomova ${ }^{1}$, Stepan A. Buriakov ${ }^{1}$, Sergei L. Vasenev ${ }^{1}$, Zhanna V. Gornostaeva ${ }^{1} \&$ Maxim V. \\ Kornienko ${ }^{1}$ \\ ${ }^{1}$ Institute of service and business (branch) Federal State Budget Educational Institution of Higher Professional \\ Education «Don State Technical University», Shakhty, Russia
}

Correspondence: Anna I. Pakhomova, nstitute of service and business (branch) Federal State Budget Educational Institution of Higher Professional Education «Don State Technical University», 346500, Shakhty, Russia.

Received: May 28, 2014 Accepted: June 11, 2014 Online Published: July 29, 2014

doi:10.5539/ass.v10n15p255 URL: http://dx.doi.org/10.5539/ass.v10n15p255

\begin{abstract}
The aim of the article is to study the localization process of reproduction of the workforce of the modern city. Transaction costs are high in two cases: when it is difficult to find a replacement for participants of market interaction, and when the number of potential participants of the market interaction is large. Localization allows optimization of the organizations demographics and thus reducing transaction costs. At that, if contractors have average specificity assets and stable contracting relations, formation of hybrid forms of integration, namely quasi-integration, is possible. This leads to the formation of inter-corporation network, which includes other existing or emerging organizations (research institutes, universities, infrastructure companies, specialized services providers, etc.). Contacts between inter-corporation network and these organizations are irregular and still do not significantly affect the efficiency of network operation and territorial-sectorial value creation system. According to M.E. Porter's terminology, such structures can be designated as quasi-cluster integrations. During the operation quasi-cluster integration can turn into a cluster, though this may not happen at its regression, i.e. degradation of the territorial-sectorial value creation system or formation of classical integration. In general, quasi-cluster integration differs from the concept of "inter-corporation network" by the fact of the geographical localization of business processes and the presence of relationships with other organizations. It differs from the cluster by the irregularity and low significance of the relationships of inter-corporation network and other organizations, as well as the existence of abruptions in the resources flow circulation and/or information within the value delivery system.
\end{abstract}

Keywords: localization, reproduction, workforce, urban

\section{Introduction}

Nowadays, the achievement of competitive advantages of contemporary national economies occurs at the expense of human resource development (Popkova \& Tinyakova, 2013; Popkova et.al., 2013; Kublin \& Popkova, 2009). It is time when health, acquired knowledge, information and experience form the basic material, which is laid the foundation of economic prosperity of the world leading countries (Popkova, 2005; Aweng \& Fatt, 2014). In this regard, the Russian policy seeks to develop national performance potential. To date, it becomes evident that the development of the performance potential of the country to ensure the efficiency of labor in the labor market becomes impossible without systematic measures on recreation the health of the working-age economically active workforce (Elsherpieny et. al., 2014; Hammadi et. al., 2014; Hassan, 2014).

At that, labor market is defined as a set of socio-economic relations between the state, employers and employees in terms of the purchase and sale of labor, workers training, and their employment in the production process (Harun, 2014; Popkov et. al., 2013; Popkova , etc., 2013).

\section{Materials and Methods}

The author uses research methods such as the system analysis method, content analysis of the scientific literature, economic and statistic method, comparative, structural and logical analysis, graphical methods of presenting information, as well as the formalization method. 
A fundamental work on the theory of the city by I. Gruz served theoretical and methodological basis of the study. The paper also is benefited by the research on theoretical and methodological issues, associated with the study of the localization processes of urban workforce reproduction, carried out by present-day Russian authors A. Marshall, M. Castells, O. Williamson, R. Coase, and S. Vasenev.

Balancing method is the basic technique for studying movement of the population and the workforce. Its core consists in the concordant definition of planned manpower needs at the regional, industry, and enterprise levels and the sources of their satisfaction. Using this method, first we identify regional manpower reserves, not involved in social production: natural increase of the working age population; number of university graduates, and retirees, who could take part in economic activity.

Lack of balancing method is that it does not take into account existing regional inter-sectorial and inter-professional processes and other types of workforce movement. As a result, it is assumed that the demand for workforce is to be met by local sources, as well as by spatial flows of population that will ensure concordance between the working-age population and the number of jobs.

Workforce movement balances reflect not only individual forms of movement, but the whole process of movement, as well as its quantitative characteristics. Balances treat movement in relation of its various forms, show a change in the industry, territorial, age-related, professional, qualification, and social structure of the workforce as a result of such a movement. Eventually, the balance makes it possible to show the unity of the socio-economic and demographic processes, associated with changes of population and workforce, as well as their respective structures (age-related, territorial, sectorial, etc.) over a certain period. This provides the basis for workforce planning.

Balances also allow evaluation of the importance of individual workforce flow traffics. At that, a quantitative assessment of the role of flows in terms of the relevance of their variations for the formation of the employment structure in the region is the criterion used to evaluate their importance. However, the balances of natural and spatial movement of population and the workforce are based on statistical reports and census data, whereas other balances are made up based on special surveys on workforce movement.

Balances are used also to make predictions of population and workforce movements, as well as the total volume of employees' arrivals and departures in various industry sectors. The most effective methods for analyzing movement of the workforce and the effectiveness of their use are the methods of economic analysis and economic-mathematical simulation.

When determining the intensity and results of natural and mechanical movement of the population, the following indicators are calculated: crude birth rate $\left(\mathrm{K}_{\mathrm{CBR}}\right)$, crude death rate $\left(\mathrm{K}_{\mathrm{CDR}}\right)$, rate of natural increase $\left(\mathrm{K}_{\mathrm{RNI}}\right)$, migration index on arrival $\left(\mathrm{K}_{\mathrm{MIA}}\right)$, migration index on departure $\left(\mathrm{K}_{\mathrm{MID}}\right)$, gross migration rate $\left(\mathrm{K}_{\mathrm{GMR}}\right)$, migration balance (of mechanical movement of the population) (MB), migration balance rate (of the mechanical movement of the population) $\left(\mathrm{K}_{\mathrm{MBR}}\right)$.

\section{Results}

In "Economic encyclopedia", labor market is considered more widely as the "sphere of contacts of buyers and sellers of labor services, where those who are willing to work (employed and unemployed) and those who employ workers to produce goods and services oppose each other". The labor market, as economic category, is a complex system of relations in terms of exchange of individual abilities to work for the means of subsistence, needed for the reproduction of the workforce, and allocation of workers in the system of social division of labor under the commodity production and circulation laws.

When speaking about the job market, we should distinguish the labor market and the workforce market. Labor market includes socio-economic relations of employed and unemployed workers, i.e. all economically active population of the country. Thus, this market includes unemployed. Workforce market is a set of socio-economic relations on the recruitment, training and use of workforce (both employed and unemployed, as well as students). This concept extends the scope of the market even wider because includes not only the economically active population, but also the students of vocational education (labor reserve).

In the scientific literature there are many approaches to disclose this concept. The urban is understood as a spatially localized economic system, which consists of the relationship between economic, social, legal and other peculiar aspects. Thus, the urban as a spatially localized economic system is a complex, structurally coherent and relatively independent system, which consists of the relationship between economic, social, legal and other aspects of its definition. 
The reason for the urban existence is a lack of human's self-sufficiency. Most people live in the urban, because the main jobs are concentrated there. Cities offer a wide range of goods and services; they provide the opportunity for a high standard of living, as well as communication and personal self-actualization. In addition to the social factors of cities emergence, one should also highlight the economic factors of jobs concentration, conditionally divided into three groups, which were distinguished by O. Sullivan:

1. Trade leads to the emergence and development of the urban only if there is transport economy of scale.

2. Internal production economy of scale enables enterprises to produce goods more efficiently than this can be done by individuals, and thus the production of goods leads to the development of industrial cities. Creating enterprise promotes emergence of factory town.

3. Production concentration and marketing effect forces firms to cluster in urban areas, thereby causing the development of large cities. Two types of concentration effect should be considered: the urbanization effect and the localization effect.

The urbanization effect appears in the case of reducing production costs of one firm in the wake of rising in the combined production within the limits of the urban. In this case, the effect is produced by the growth of urban economy of scale that benefits all of urban businesses. The urbanization effect appears for the same reasons as the localization effect. Firms conjointly use the services of the same suppliers. Large cities provide a single common labor market. Urban environment contributes to innovation, since technological progress markedly affects the factors of urban development.

Localization effect takes place if the cost of production at enterprises decreases as the total production of the companies in the industry grows. It is based on three reasons: economies of scale of intermediate factors of production, the formation of common job market and knowledge mobility.

The concept of "urban" consists of three interrelated open subsystems: social structure, spatial structure and economic structure (Fig.1).

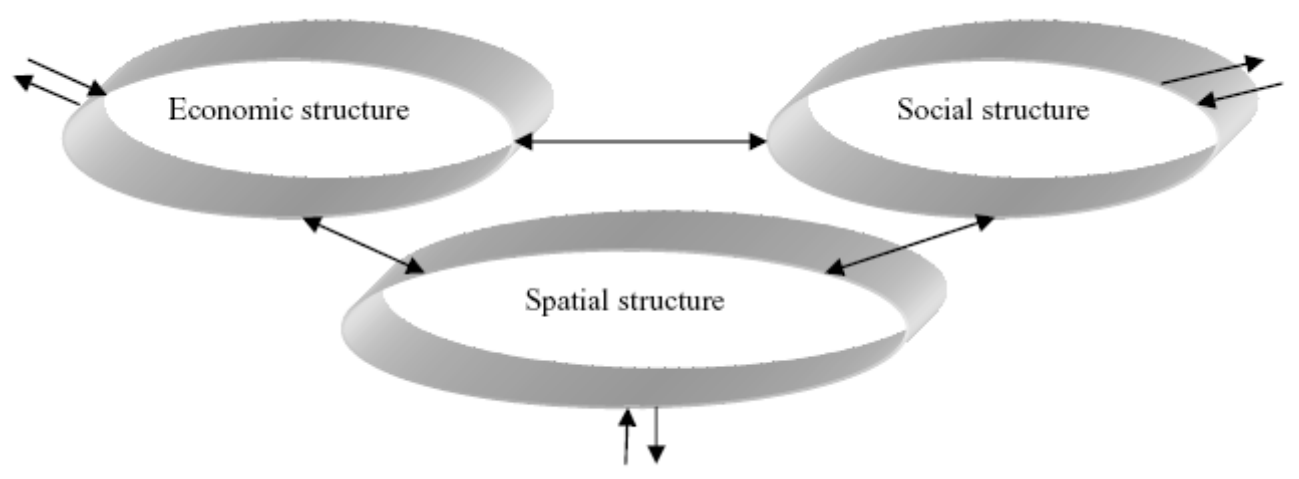

Figure 1 . The concept of an urban as a spatially localized economic system

The urban economic structure is a self-developing economic system, allowing one to focus financial, labor, transport and productive resources.

Urban spatial or territorial planning structure is formed by the territories of different purposes. These are so-called functional areas: industrial, residential, municipal and warehouse zones, external transport zones, recreational and other zones, closely interacting between each other.

A communications network plays essential role in the urban structure, providing links between its elements.

The urban spatial structure is largely determined by its size, as well as economic, demographic and social peculiarities of the urban milieu; relationships with the environment, the creation and development of the urban political and legal grounds, as a specific territorial phenomenon, and in particular, by the adoption of urban charters. 
Development of social structure includes key issues of social policy aimed at improving the population's quality of life, increased well-being and longevity, the formation and reproduction of healthy, creatively active generation.

Status of the social sphere is one of the key indicators of the urban development, as it reflects the level and quality of life, and also determines the level of civil initiatives in accordance with the cultural and educational potential of the city.

Among the external factors that determine urban social development, we should identify the following:

globalization of social and cultural space;

transition to the market, accompanied by the transformation of the value system, prevailing in society;

changes in the institutional environment;

environmental degradation on a global and local levels.

The following are specific characteristics that can be attributed to internal factors of the urban social environment status:

1. the lack of civil society development that is manifested by low social activity of the citizens, the lack of local government development, and the conflict of interests between groups;

2. the crisis of value system, in particular, strengthening the proneness to conflict in society, criminalization, increase in drug use among population, and the degradation of tolerance;

3. social differentiation and spatial segregation of society, the lowest proportion of the middle class in the social structure, the loss of the urban community traditions, unequal access to social services for a various strata of the population.

\section{Discussion}

Thus, social infrastructure is an integral part of the urban system, and the problems of its development should be considered comprehensively, in close connection with other subsystems of the urban system.

Based on an assessment of urban infrastructure, we can talk about the development prospects of each of its elements, because a strategic urban development plan should contain a selection of activities that contribute to the improvement of the existing infrastructure, as well as strategic vision, suggesting the analysis of development factors to determine the sustainable competitiveness (Vasenev, 2012).

Nature of urban infrastructure should comply at any time with current findings of this intelligence. But speaking of the development factors, one should always bear in mind the relativity of advantages and disadvantages: what today seems like a disadvantage may become a decisive advantage under certain circumstances. Thus, chronic backwardness of production facility requires a large-scale technical modernization program with the expectation of rapid economic growth (Gruza, 1972). However, then the plans on social improvement may be delayed. Here we can formulate hypotheses about the possible development scenarios (predictions) making the best use of the strong points, and avoiding the aggravation of problems, hindering development.

In this regard, infrastructure appears the condition of forecast stabilization, therefore the course of its improvement is usually considered among the most important processes of urban development, such as demographic, economic, environmental and political issues. In addition, because the infrastructure provides the habitability of the city, it is impossible to postpone its development without complications of the above-mentioned processes.

The main objective of the urban development is to provide life-sustaining activity of the people, expanding economic space, creating new conditions for the successful development of small and large businesses, implementation of innovation and much more (Coase, 1960). Solution to such problems directly depends on the development of the urban economy, which is some basic resource for economic development. Key to the success for its implementation is the harmonious development of all elements of the urban economy (Nutsubidze et. al., 2013).

In economic science of the 1990s the issues related to regionalization of functioning of socio-economic systems became quite popular. They have examined the interaction mechanisms between system elements within the defined spatial localization (Williamson, 1996). It should be noted that the above-mentioned research domain was initiated by the works of Alfred Marshall. "Principles of Economics" substantiates the historical character of localizations that emerged due to the following reasons: natural conditions, the protection of the Quirinal and a deliberate policy of the government (Marshall, 1993). Functioning of locations gave advantages to the 
enhancement of exchange of ideas, to the development of ancillary industries and specialization, to skilled labor market grouping, to the development of wholesale and rational distribution of production (Castells, 2000). The main disadvantage of localizations was excessive concentration of mono-industry sector that requires a workforce with specific property or labor skill.

\section{Conclusion}

Territorial concentration of the economic system elements predetermines the locality of bargains and the localization of transactions, which are formed in both the geographical and socio-institutional space; a network is formed, i.e., a special form of the external environment of an economic entity. Number of transaction network participants is finite that significantly affects their performance. Most participants do not compete directly, but serve different segments of the industrial sectorial market; at the same time, competition is maintained in some parts of the value chain. In addition, they face many similar barriers on the way of increasing the productivity of economy management that creates prerequisites for long-term cooperation.

Annihilation of redundant transactions is one of the main ways to optimize the functioning of the socio-economic systems, which is often implemented through integration mechanism. From the perspective of transaction costs, integration processes lead to savings by combining sales and delivery resources. Though, the total amount of transaction costs depends on the number of transactions and the number of subjects involved.

During the operation, quasi-cluster integration may turn into a cluster, though this may not happen at its regression, i.e. the degradation of the territorial and industrial value delivery system or formation of classical integration. In general, quasi-cluster integration differs from the concept of "inter-corporation network" by the fact of the geographical localization of business processes and the presence of relationships with other organizations. It differs from the cluster by the irregularity and low significance of the relationships of inter-corporation network and other organizations, as well as the existence of abruptions in the resources flow circulation and/or information within the value delivery system. Abruption in resources and/or information circulation flow may be full, partial or even be absent. It may not be executed in full, as well as be vertical, i.e. abruption of the quasi-integration interrelations vertically: "supplier $\rightarrow$ manufacturer $\rightarrow$ consumer"; and horizontally, i.e. abruption of inter-sectorial quasi-integration interrelations.

The limitations of the present work lie in its theoretical nature and complexity of practical application. It is supposed to use the obtained results of the study on the urban workforce management by local authorities. Prospects for further study of the urban workforce reproduction localization problem are associated with the fact that the study of localized socio-economic systems under the Russian conditions is approaching the topical area of urban and urban agglomerations development. Objective diversity and significant proportions of individual regions complicate networking at the regional level. Therefore, attention should be directed to the study of subnational entities through the prism of the urban concept.

\section{References}

Aweng, E. R., \& Fatt, C. C. (2014). Survey of potential health risk of rubbish collectors from the garbage dump sites in Kelantan, Malaysia. Asian Journal of Applied Sciences, 1, 5-11.

Castells, M. (2000). Information age: Economy, society and culture (p. 608). M.: HSE.

Coase, R. (1960). The Problem of social cost. Journal of Law and Economics, 3(1), 12.

Elsherpieny, E. A., Hassan, A. S., \& El Haroun, N. M. (2014). Application of generalized probability weighted moments for skew normal distribution. Asian Journal of Applied Sciences, 1, 14-18.

Gruza, I. (1972). Urban theory (p. 247). M.: Stroyizdat.

Hammadi, K. J., Al-Molla, A. K. J., \& Al-Maadhdei, M. E. (2014). Genetic relatedness among Iraqi, Jordanian and Iranian TYLCV based on the identity analysis.

Hassan, S. M. (2014). Electromagnetic therapy control the effect of bacteria on liver tissue: Histopathological, histochemical and immunohistochemical studies. Asian Journal of Applied Sciences, 1, 23-25.

Kublin, I. M., \& Popkova, E. G. (2009). Marketing problems in market relations. Bulletin of VSTU, Series "Actual problems of reforming the Russian economy (theory, practice, perspective)", 9(5), 74-78.

Marshall, A. (1993). Principles of economics. V.3. Moscow: Progress Publishers.

Nutsubidze, A. S., Rodina, E. A., Gornostaeva, Z. V., \& Alehina, E. S. (2013). Theoretical foundations of industrial enterprise management. World Applied Sciences Journal, 28(10), 1463-1468.

Popkova E. G., Shahovskaya, L. S., Romanova, M. K., \& Dubov Y. I. (2013). Basis for transition of the territory 
to sustainable development: City. World Applied Sciences Journal, 1, 1499-1507.

Popkova, E. G. (2005). Institutes and new quality of economic growth. Bulletin of VSTU, Series "Actual problems of reforming the Russian economy (theory, practice, perspective)", 9(5), 15-23.

Popkova, E. G., \& Tinyakova, V. I. (2013). Drivers and contradictions of formation of new quality of economic growth. Middle-East Journal of Scientific Research, 15(11), 1635-1640.

Popkova, E. G., Chashchin, V. V. \& Bogdanov, D. V. (2013). Implementation of the concept of personnel marketing in modern Russia. World Applied Sciences Journal, 22(3), 389-395.

Popkova, E. G., Morkovina, S. S., Patsyuk, E. V., Panyavina, E. A., \& Popov, E. V. (2013). Marketing strategy of overcoming of lag in development of economic systems. World Applied Sciences Journal, 5, 591-595.

Vasenev, S. L. (2012). Fundamentals of performance monitoring of quasi-cluster integrations. Bulletin of the North-Caucasian Institute for the Humanities, 1, 24-34.

Williamson, O. (1996). Economic institutions of capitalism. Firms, markets and relational contracting (p. 653). St. Petersburg: Lenizdat.

Yusof, Z. M., Misiran, M., \& Harun, N. H. (2014). Job satisfaction among employees in a manufacturing company in North Malaysia. Asian Journal of Applied Sciences, 1, 26-29.

\section{Copyrights}

Copyright for this article is retained by the author(s), with first publication rights granted to the journal.

This is an open-access article distributed under the terms and conditions of the Creative Commons Attribution license (http://creativecommons.org/licenses/by/3.0/). 